ANUARIo DE Estudios MEDIEVAles (AEM)

36/2, julio-diciembre de 2006

pp. 583-611

ISSN 0066-5061

\title{
LAS COFRADÍAS DE LA VERA CRUZ Y DE LA SANGRE DE CRISTO EN LA CORONA DE ARAGÓN $\left(\right.$ SIGLOS XIV-XVI) ${ }^{1}$
}

\section{GERMÁN NAVARRO ESPINACH Universidad de Zaragoza}

Resumen: Cofradías de la Vera Cruz se fundaron desde el siglo XIV en algunas ciudades de la Corona de Aragón como Xàtiva, Valencia, Zaragoza o Requena. En contraste, muchas cofradías de la Sangre de Cristo nacen en el siglo XVI o más tarde. Ambos tipos de asociaciones estuvieron compuestas por nobles, clérigos, burgueses y labradores, y en muchos casos fueron promovidas directamente por la monarquía o la Iglesia. Son las primeras cofradías de la Pasión o de Semana Santa que hubo en España. En este artículo estudiamos los textos de ordenanzas hoy conocidos en la Corona de Aragón, incluyendo otras noticias sobre las diversas reliquias relacionadas con la advocación de estas cofradías.

Palabras clave: Cofradías, Reliquias, Semana Santa, Vera Cruz, Sangre de Cristo, Corona de Aragón, siglos XIVXVI.

\begin{abstract}
Fraternities of True Cross were founded in the XIVth century or later in some cities of the Crown of Aragon like Xàtiva, Valencia, Zaragoza or Requena. In contrast, a lot of fraternities of Christ's Blood were born in the XVIth century or later. Both of them were composed by nobles, priests, bourgeoisie and peasants, and were promoted directly by the monarchy and the Church. They were the first fraternities of Passion or Holy Week that we know in Spain. In this article we study the most important ordinances that we find today in the Crown of Aragon, including others records about some relics, subject that has to do with the dedication of these fraternities.
\end{abstract}

Key-words: Fraternities, Relics, Holy Week, True Cross, Christ's Blood, Crown of Aragon, XIVth-XVIth centuries

\section{SUMARIO}

1 - La hipótesis de Sánchez Herrero como punto de partida. 2 - El auge de las reliquias del Lignum Crucis y las apologías de la Santa Cruz. 3 - El Santo Grial, los Corporales, la fiesta del Corpus Christi, los Disciplinantes y la Sangre de Cristo. 4 - Las cofradías de la Vera Cruz desde el siglo XIV: Xàtiva, Valencia, Zaragoza y Requena. 5 - Las cofradías de la Sangre de Cristo desde el siglo XVI: Zaragoza, Castellón, Alcoi, Cullera y otras muchas. 6. Balance provisional.

\footnotetext{
${ }^{1}$ El presente estudio se integra en el proyecto de investigación interuniversitario Migraciones, élites económicas e identidades culturates en la Corona de Aragón (1350-1500), dirigido por el profesor Paulino Iradiel y subvencionado por el Ministerio de Educación y Ciencia durante 2005-2008 (referencia HUM2005-04804/HIST).
} 


\section{LA HIPÓTESIS DE SÁNCHEZ HERRERO COMO PUNTO DE PARTIDA}

Siempre me ha interesado el asociacionismo medieval a la luz de la documentación generada por las corporaciones artesanales o las cofradías de oficio. Sin embargo, de un tiempo a esta parte, quizás por la tenue frontera que separa ambos mundos, el estudio de las cofradías religiosas atrae con fuerza mi atención. Todo comenzó con un primer artículo que publiqué en 2000 en el homenaje al profesor Ángel San Vicente en torno a la cofradía de Santa María de Villaespesa y de San Juan Bautista de Teruel, gestora del hospital más importante de esta ciudad en el tránsito del siglo XV al $\mathrm{XVI}^{2}$. Era la primera vez que me enfrentaba a una institución ciudadana de estas características en la que la profesión no constituía el fundamento de la identidad cultural de sus integrantes, sino que ésta venía dada por una doble advocación religiosa volcada hacia la práctica benéfico-asistencial. En esas circunstancias, tres años después, los días 8 y 9 de marzo de 2003, el profesor Vidal Muñoz me invitó a participar como ponente en las Segundas Jornadas Nacionales de las Cofradías de la Sangre de Cristo, celebradas entonces en Rubielos de Mora (Teruel), con el objetivo de que presentase un estado de la cuestión sobre las cofradías religiosas medievales en la Corona de Aragón. La primera conferencia nacional de estas cofradías de la Sangre había tenido lugar el año anterior en la ciudad de Teruel durante los días 15-17 de febrero. En aquella primera reunión fue el profesor Vicente Ángel Álvarez Palenzuela quien pronunció una conferencia sobre la religiosidad de los laicos en la Baja Edad Media a través de cofradías, hermandades y asociaciones asistenciales. Estuve invitado después a las Terceras Jornadas Nacionales de las Cofradías de la Sangre de Cristo en Alcorisa (Teruel), los días 25 y 26 de febrero de 2005, donde coincidí en esta ocasión con el profesor José Sánchez Herrero, quien abordó el tema del culto a la Sangre de Cristo durante los siglos XIII-XVI. En este último contexto y tras varias conversaciones que tuvimos aquellos días, el profesor Sánchez Herrero me invitó a participar como ponente en el futuro Congreso Internacional de Cofradías de la Santa Vera Cruz a celebrar en Zamora en septiembre de 2008 bajo su coordinación ${ }^{3}$, con el objetivo de poner al día las investigaciones que se hubiesen desarrollado sobre esta temática en los países de la Corona de Aragón. Yo también trataría de comprobar si su hipótesis sobre el origen de las cofradías y procesiones de Semana Santa en la

\footnotetext{
${ }^{2}$ G. NAVARRo Espinach, El Hospital de Santa María de Villaespesa y de San Juan Bautista en la ciudad de Teruel a través de los actos notariales de Alfonso Jiménez (1481-1518) en "Aragón en la Edad Media", XVI (2000), Homenaje al profesor emérito Angel San Vicente Pino, pp. 565-590.

${ }^{3}$ El primer congreso se celebró en Sevilla en 1992 y el segundo en Caravaca en 2000. Véase J. SÁNCHEZ HERRERO (dir.), Las cofradías de la Sạta Vera Cruz, Actas del I Congreso Internacional de Cofradías de la Santa Vera Cruz (Sevilla, 19-22 de marzo de 1992), Sevilla, Centro de Estudios e Investigación de la Religiosidad Andaluza, 1995; y M. GARCíA-EsTELLER y D. MARTÍN (eds.), Actas del II Congreso Internacional de la Vera Cruz (Caravaca, 12-15 de octubre de 2000), Murcia, Caja de Ahorros, 2002
} 
Corona de Castilla se comprobaba para los territorios de la corona aragonesa.

El profesor Sánchez Herrero se inclina a pensar que al menos dos o tres fenómenos de orígenes independientes acabaron por converger en el origen de las cofradías castellanas de Semana Santa. En concreto alude al culto a la Vera Cruz en sentido pasionario, la devoción a la preciosísima Sangre de Cristo o el movimiento de los disciplinantes. Incluso, la devoción a la Sangre de Cristo, muy extendida en los siglos XV-XVI, pudo influir en el cambio del culto a la Santa Cruz, dejando de verla como la Cruz gloriosa donde Cristo vence, para convertirse poco a poco en la Cruz dolorosa en la que Cristo muere. En suma, sin negar la divinidad de Jesucristo, se asiste a la progresiva humanización de su figura, especialmente a partir del siglo XIII de la mano de autores como San Francisco de Asís. Por consiguiente, según Sánchez Herrero, la devoción a la Sangre de Cristo transformará el culto a la Cruz, entendida cada vez más como el lugar donde Cristo ha sufrido su Pasión y ha muerto. Y la aparición de los movimientos de disciplinantes y flagelantes con San Vicente Ferrer en el siglo XV terminará por gestar la eclosión definitiva de las cofradías de la Pasión o de Semana Santa ${ }^{4}$. Así, pues, con esta hipótesis como punto de partida, a continuación quiero exponer los resultados provisionales que desde hace un año vengo recogiendo sobre la Corona de Aragón con la mente puesta en el congreso que se celebrará en Zamora en 2008.

\section{EL AUGE DE LAS RELIQUIAS DEL LIGNUM CRUCIS Y LAS APOLOGÍAS DE LA SANTA CRUZ}

Guiberto, abad de Nogent, reconstruyó en una crónica escrita en 1109 sobre la Primera Cruzada los argumentos del papa Urbano II en su alocución del concilio de Clermont (1095), incluyendo la siguiente pregunta: ¿por qué rehusáis descubrir la cruz, la sangre de Cristo y su tumba, visitarlas y salvar vuestras almas al hacerlo ? $^{5}$. Pocas semanas después de la conquista de Jerusalén el día 5 de agosto de 1099 una parte de la Vera Cruz fue redescubierta. Siglos antes había sido allí mismo donde se creía que la madre del emperador Constantino, santa Elena, encontró un gran

${ }^{4}$ La formulación más reciente de esta hipótesis en J. SÁNCHEZ HERRERO y S. M. PÉREZ GonzÁlez, La Cofradía de la Preciosa Sangre de Cristo de Sevilla. La importancia de la devoción a la Preciosa Sangre de Cristo en el desarrollo de la devoción y la imaginería de la Semana Santa en "Aragón en la Edad Media" XIV-XV (1999). Homenaje a la profesora Carmen Orcástegui Gros, tomo II, pp. 1429-1445. Véase también J̀. SÁNCHEZ HERRERO (editor), Reglas de hermandades y cofradias andaluzas. Siglos XIV, X $\dot{V}$ y XVI, Universidad de Huelva, 2002 .

${ }^{5}$ Véase L. GARCÍA-GUIJARRO RAMOS, Perfección espiritual y guerra por la fe en el transcurso de la Primera Cruzada en "Acta Historica et Archaeologica Medievalia", 26. (2005), Homenatge a la Professora Dra. Carme Batlle i Gallart, pp.125-149. La cita y traducción de la crónica Dei Gesta per Francos en p. 137. 
trozo del madero donde fue crucificado Jesús de Nazaret ${ }^{6}$. Entre los cruzados y peregrinos que volvieron a sus países con una reliquia del Lignum Crucis hubo monarcas y altos dignatarios, algunos de los cuales obsequiaron con ella a diversos monasterios, y tanto las reliquias como sus receptáculos fueron puntos de cristalización de la devoción popular. Un estudio comparativo de la Vera Creu d'Anglesola con otros relicarios coetáneos ha mostrado que ésta fue fabricada efectivamente en Jerusalén en la segunda mitad del siglo XII. Y parece verosímil que fuera llevada a Urgell por los mismos canónigos del Santo Sepulcro ${ }^{7}$. Resulta pues cada vez más evidente que la advocación y la reliquia del santo Lignum Crucis o de la Santa Vera Cruz no son fenómenos anteriores al siglo XII en la Península Ibérica, si se deja bien claro de una vez por todas que una cosa es la leyenda o la tradición de la antigüedad de un culto y otra bien distinta los documentos históricos que refrendan su existencia real o no ${ }^{8}$.

La devoción a la Vera Cruz a través de fragmentos de madera convertidos en reliquias es un precedente lejano del siglo XII de lo que mucho tiempo después a partir del siglo XIV fue la institucionalización colectiva de dicho culto en forma de cofradías. En concreto, la primera noticia que tengo al respecto alude al rey Alfonso I el Batallador (1104-1134), a quien los monjes de Sahagún le acusan en su crónica anónima de haberse llevado del monasterio el Lignum Crucis, regalo del emperador Alejo. El profesor Lacarra escribía que el rey lo llevaba honoríficamente en su capilla regia ambulante en el interior de un arca de oro puro ornada con piedras preciosas, junto con otros muchos relicarios. Según Lacarra, este hurto era perfectamente parangonable con el que cometió el arzobispo Gelmírez cuando robó en Braga el cuerpo de San Fructuoso, calificado, sin embargo, por el propio autor del mismo como "pío latrocinio".

La crónica de San Juan de la Peña, compuesta a instancias de Pedro IV entre 1369 y 1372 para servir de preámbulo posiblemente a la crónica de su reinado, contiene una referencia significativa al rey Jaime I en vísperas de su muerte en 1276: el dito santo rey se fizo adozir delant sí la santa verdadera Cruz de Ihesu Christo quel avía en uno de los sus cof-

${ }^{6}$ J. SÁNCHEZ HERRERO, La devoción a la Cruz de Cristo, siglos IV al XV en M. GarcíaEsteller y D. Martín (eds.), Actas del II Congreso Internacional de la Vera Cruz, citado, pp. 19-53. ${ }^{7}$ N. JASPERT, Un vestigio desconocido de Tierra Santa: la Vera Creu d'Anglesola en
"Anuario de Estudios Medievales", 29 (1999), pp. 447-475. Otro ejemplo de este tipo de piezas ha sido estudiado por J. FERRE PUERTO, L art medieval a la Vall d'Albaida. La Vera Creu d'Albaida $i$ el seu context en el catálogo de la exposición 750 anys com a valencians: Albaida i la Vall, 1245-1995, Ontinyent, 1995, pp. 195-211.

${ }^{8}$ Así insiste en subrayarlo con toda razón el profesor Joșé Sánchez Herrero en su ponencia La devoción a la Cruz de Cristo..., citado, pp. 34 o 41 y siguientes.

${ }^{9}$ J. M. LACARRA, Alfonso el Batallador, Zaragoza, Guara Editorial, 1978, p. 118. Véase también M. L. LEDESMA RUBIO, Alfonso I en R. Centellas Salamero (coord.), Los Reyes de Aragón, Zaragoza, Caja de Ahorros de la Inmaculada, 1993, pp. 41-49. 
fres $^{10}$. La crónica de Aragón de Gauberto Fabricio de Vagad (1499) recrea de la siguiente manera la muerte de Jaime I:

\begin{abstract}
mando el cristianissimo rey que le truxiessen delante un pedaço de la sancta vera cruz de nuestro redemptor y señor Jhesucristo; en la qual el tenia muy entrañable devocion, y tenia de grandes tiempos muy guardada en sus cofres reales para se della guarnecer y ayudar en la afruenta de la muerte, y puesta entre los braços odorola con devocion muy grande y dixo... ${ }^{11}$.
\end{abstract}

Esa información no aparece ni en la crónica de Bernat Desclot, finalizada hacia 1286-1288, ni en el propio Llibre dels Feits del rey, del que no conocemos el texto original anterior al de Desclot sino una versión de 1343. Sólo la crónica de Ramón Muntaner, escrita entre 1325 y 1336, alude a la muerte de Jaime I de la siguiente manera: ab les mans encroades posant sobre son pits, dix l'oració que nostre senyor ver Déus Jesucrist dix en la creu $^{12}$

En este punto, es curioso observar que el mismo Muntaner refleja en la citada crónica datos sobre su devoción personal a la Vera Cruz. Por ejemplo, cuando los sicilianos piden ayuda al rey Pedro III, Muntaner pone en su boca estas palabras:

nós venim a la santa reial majestat vostra de part d'aquell orfe poble a clamar mercè a vós, que sia de gràcia e de mercè vostra que per la santa passió que Déus pres en la vera creu per l'humanal llinatge, que vós hajats mercè d'ells e pietat e que els acorregats e els gitets d'aquella dolor en què ells estan ${ }^{13}$.

De la misma manera pasa a describir la muerte de Pedro III en 1285 como la de otro monarca devoto de la Santa Cruz:

féu-se donar una creu que li estava davant, e reebé-la en ses mans, plorant ab gran devoció; e dix molta bona oració. E con ho hac fet, llevà los ulls al ceel, e senyà's tres vegades, e puis abraçà la creu, e encroà los braços sobre ella, e dix: -Pare senyor ver Déus Jesucrist, en les vostres mans coman lo meu esperit. Plàcia-us, per la santa passió que presés per nós, pecadors, que reebats la mia ànima en paradís... ${ }^{14}$.

\footnotetext{
${ }^{10}$ Crónica de San Juan de la Peña (versioón aragonesa), edición crítica de C. Orcástegui Gros, Zaragoza, Institución Fernando el Católico, 1986, p. 94.

${ }^{11}$ G. F. VAGAD, Corónica de Aragón, edición facsimilar de la obra impresa en 1499 con introducción a cargo de C. Orcástegui Gros, Zaragoza, Cortes de Aragón, 1996, f. LXXXVIv..

${ }^{12}$ R. MUNTANer, Crònica, 2 vols., edición de M. Gustà, Barcelona, Edicions 62 i "la Caixa", 1979 , vol. I, cap. 28 , p. 56

${ }^{13}$ Ibídem, vol. I, cap. 54, p. 90

${ }^{14}$ Ibídem, vol. I, cap. 146, pp. 231-232.
} 
La agonía final de sus hijos y sucesores los reyes Alfonso III en 1291 y Jaime II en 1327 son descritas por Muntaner de manera similar, con los monarcas abrazados a la cruz encomendando sus espíritus a Dios ${ }^{15}$.

Pienso que la atracción especial que ejercía la Vera Cruz en el cronista Ramón Muntaner fue lo que hizo que incidiese en relatar la muerte de los monarcas aragoneses de esa manera, al margen de que fuera verdad o no. De hecho, en un pasaje de su crónica dedicado a la conquista de Éfeso confiesa que recibió por suerte como botín una reliquia valiosísima que el mismísimo San Juan Evangelista dejó en la iglesia de aquella ciudad:

\begin{abstract}
un tros de la Vera Creu, que monsènyer sant Joan Evangelista llevà ab la sua man de la Vera Creu, d'aquell lloc on Jesucrist havia tengut lo cap; e aquell tros era molt ricament encastat en aur, ab pedres precioses, que valien sens nombre (que fort cosa vos seria de creure, qui us ho contava, ço que entorn li era encastat); e ab una cadeneta d'aur que hi havia, monsènyer sant Joan tots temps portava-la al coll.
\end{abstract}

Obsérvese, pues, cómo en el reparto de las reliquias encontradas en el botín de Éfeso, Ramón Muntaner confiesa en primera persona que: a mi venc per sort la Vera Creu ${ }^{16}$.

Parece confirmarse en la documentación que Jaime II también sentía gran devoción por la Vera Cruz. En una carta del rey escrita en 1322 y dirigida a dos ciudadanos barceloneses para su embajada ante el sultán de Egipto les indica que le pidan en su nombre como han hecho otros príncipes y altos cristianos del mundo que le facilite un trozo de la Santa Cruz porque haia gran devoció en la Vera Creu y sabe que el sultán tiene fragmentos en gran cantidad en su tesoro junto a otras reliquias ${ }^{17}$.

La segunda nuera del rey Jaime II también era fiel amante de la Vera Cruz. Me refiero a Leonor de Castilla (1307-1359), esposa de Alfonso IV de Aragón e hija de Fernando IV de Castilla y de Constanza de Portugal. Leonor fundó la cofradía de la Vera Cruz de Xàtiva en 1333 como tendré oportunidad de explicar más adelante. En el preámbulo de las ordenanzas de esta cofradía que aprobó su hijastro el rey Pedro IV en 1381 se dice claramente:

...sots títol, reverència, nom e invocació de nostre Senyor Déu Jhesuchrist e de la gloriosa Verge sancta Maria, mare de aquell e de la santa vera Creu en la qual Jhesuchrist per salvació del humanal linatge volch sostenir per si, la qual confraria fo a principis instituida e per la molt

\footnotetext{
${ }^{15}$ Ibídem, vol. II, caps. 174 y 292, pp. 33 y 200 respectivamente.

${ }^{16}$ Ibídem, vol. II, cap. 234, p. 114.

${ }^{17}$ Este documento es citado y comentado por A. BELTRÁn, Estudio sobre el Santo Cáliz de la catedral de Valencia, Valencia, 1960, p. 42.
} 
alta Senyora Reyna dona Elionor ladonchs Reyna d'Aragó, possehidora de la dita ciutat, aprovada ab privilegi seu... ${ }^{18}$.

Y poco después se escribe también que los propios cofrades, conscientes de la devoción manifestada igualmente por el mismo rey Pedro IV, han decidido solicitarle estas nuevas ordenanzas:

los dits confrares considerants la cordial devoció del dit Senyor Rey per la qual pres, te e porta sobre lo cor lo senyal de la creu. E volents quasi famular a ell en los dits senyal o devoció segons los antichs predecessors lurs havien ordenat e acustumat... ${ }^{19}$

Al menos uno de los hijos de Pedro IV heredó de su padre esta tradición familiar de los reyes de Aragón en calidad de fieles devotos de la Vera Cruz. Tras la muerte de Juan I en 1396 en un accidente de caza, su hermano y sucesor Martín I se encontraba en Sicilia y, de vuelta a Aragón, hizo un alto en Aviñón para rendir homenaje por los reinos de Córcega y Cerdeña a Benedicto XIII, el papa Luna. La estancia se prolongó durante seis semanas en que el papa y el monarca compartieron conversaciones y amistad. En el momento de la despedida, el pontífice regaló al rey un gran fragmento de la Vera Cruz, del cual el rey, a lo largo de su existencia, extrajo santas astillas en momentos muy especiales para recompensar a los suyos. Dicha reliquia debió ser la estrella indiscutible de la fabulosa colección de reliquias de Martín I, que como dice la crónica de Vagad:

tenia su real capilla tan guarnecida fermoseada y compuesta, y de tantos arreos acompañada, que pareçia mas capilla de papa que de rey secu$\operatorname{lar}^{20}$.

El inventario inédito de las reliquias que regaló el difunto clérigo Dionisio Sánchez Muñoz a la iglesia parroquial de San Pedro de Teruel, y que él a su vez había heredado de su difunto tío Gil Sánchez Muñoz, obispo de Mallorca tras su renuncia como antipapa Clemente VIII, el cual, asimismo, había hallado dichas reliquias entre los restos del papa Benedicto XIII en el castillo de Peníscola, viene a confirmar que el papa Luna seguía poseyendo siempre junto a sí la fusta de la Vera Cruz y otras reliquias relacionadas directamente con la Pasión de Cristo:

\footnotetext{
${ }^{18}$ F. DE BOFARUll y DE SARTORIO, Gremios y cofradías de la antigua Corona de Aragón (I), tomo XL de la Colección de Documentos Inéditos del Archivo General de la Corona de Aragón, Barcelona, 1876, doc. XLVIII, pp. 205-234. La cita textual en p. 206.

${ }^{19}$ Ibídem, p. 207.

${ }^{20}$ La noticia del regalo del papa Luna a Martín la recoge M.C. GARCía HERRERo, Martín I en R. Centellas Salamero (coord.), Los Reyes de Aragón, Zaragoza, Caja de Ahorros de la Inmaculada, 1993, pp.135-142, concretamente en p. 138. Esa información procede de D. GIRONA I LLAGOSTERA, Itinerari del rey en Martí (1396-1402) en "Anuari de l'Institut de Estudis Catalans" IV (1911-1912), pp. 81-184. La referencia textual de la crónica de Vagad en G.F. VAGAD, Corónica de Aragón, citada, f. CLII vo
} 
el pilar en el qual Nuestro Sennor fue açotado, la fusta de la lança de Longinos, el arca de los Santissimos Corporales, y hasta la tierra del Sancto Sepulcro ${ }^{21}$.

Dos décadas después de la muerte de Martín I, un documento notarial fechado el 18 de marzo de 1437 se refiere al depósito de reliquias y joyas realizado a favor de la catedral de Valencia por el rey Juan de Navarra (futuro Juan II de Aragón) en nombre de su hermano Alfonso V el Magnánimo. En dicho escrito se hace inventario de los diversos objetos entregados a la catedral y en primer lugar del listado se lee:

Primo una taula de fust cuberta d'or a la una part en la qual ha un tros del fust de la Vera Creu en dues creus de larch de un palm e mes ab la pietat al peu de la dita Vera Creu e dos àngels petits als costats tots smaltats d'or ab una cuberta de vellut de tripa vert ${ }^{22}$.

Otro inventario, en esta ocasión el de la biblioteca de la reina María de Castilla, esposa de Alfonso V el Magnánimo, reseña un manuscrito con la traducción catalana del Specchio di Croce del escritor dominico fray Domenico Cavalca, nacido hacia 1270 cerca de Pisa. El título de la traducción es Mirall de la Creu y en el comienzo de la misma se lee:

Aquest sant libre, per devoció de la molt alta e molt excel-lent e virtuosa senyora la senyora dona Maria, per la gràcia de Déu regina, muller del molt alt e il·lustre senyor don Alfonso, per gràcia de Déu rey d'Aragó, és stat portat del realme de Nàpollos per lo religiós frare Bernat Vilalta, monge de Nostra Dona de Montserrat, en lengua toscana. E és stat trasladat de aquella lengua en aquesta cathalana per lo religiós frare Pere Busquets, monge de Sant Phaliu de Guíxolls... ${ }^{23}$.

He leído con atención esta obra y me ha impactado especialmente la apología que hace de la Santa Cruz en que murió Jesús como ejemplo de vida, sacrificio, penitencia y baño de sangre. El culto a Cristo crucificado y sangrante está por todas partes. Sobre este último aspecto que impregna de manera clave toda la obra de Cavalca volveré en el siguiente apartado. Quiero adelantar, sin embargo, que la reina María fue la promotora principal de la cofradía de la Vera Cruz de Zaragoza al regalar al convento del Carmen de esta ciudad una reliquia del Lignum Crucis en 1450, tal y como luego tendré oportunidad de explicar.

\footnotetext{
${ }^{21}$ De próxima publicación este inventario junto a otros materiales inéditos en G. NAVARRO ESPINACH y C. VILLANUEVA MORTE, Gil Sánchez Muñoz (1370-1447), el antipapa Clemente VIII. Documentación inédita de los archivos de Teruel en "Anales de la Universidad de Alicante. Historia Medieval", en prensa.

${ }^{22}$ Este documento del Archivo de la Catedral de Valencia aparece fotografiado y puede leerse con claridad en la fig. 3 del libro de A. BELTRÁN, Estudio sobre el Santo Cáliz, citado, con su localización archivística en p. 129.

${ }^{23} \mathrm{D}$. CAVAlCA, Mirall de la Creu. Versió catalana del segle XV per Pere Busquets, 2 vols., edición de A. Gallina, Barcelona, Barcino, 1967, vol. I, p. 23.
} 
Algunos sermones de otro dominico, San Vicente Ferrer (13501419), de gran influencia en la cultura popular del tránsito del siglo XIV al siglo XV, tienden también a la apología de la Vera Cruz. En ese sentido, cabe citar en primer lugar su Sermo Exaltationis Sancte Crucis en la festividad del 14 de septiembre. En él dice San Vicente que la Santa Cruz era un portento de milagros y no dudaba en instruir a sus seguidores disciplinantes en dicha devoción: Ara fets axí: posat-vos davant lo crucifixi agenollat, e mirant-lo fets la creu sobre lo cor moltes vegades. En otro momento recomendaba asimismo que antes de comer se santigüasen y pronunciasen el nombre de Jesús: a dinar, ans que mengets, feu lo senyal de la creu, e almenys digau "Jesús"... ${ }^{24}$ Por supuesto, hay que citar también su sermón pronunciado en la conmemoración de la Invención de la Santa Cruz (fiesta del 3 de mayo), donde comienza con una arenga clara hacia el público asistente para que practique la penitencia corporal: fem festa de la $\mathrm{creu}^{25}$. En este punto viene a colación la difundida carta que el doctor Ortiz envió desde Roma a los cofrades de la Vera Cruz de Toledo el 5 de febrero de 1535, en la que se exponían contraargumentos a las objeciones realizadas por Gerson a San Vicente Ferrer sobre la práctica de esta exacerbada disciplina pública, puesto que podía ir en detrimento de la salud de los cofrades que la ejercitasen ${ }^{26}$.

Reyes y papas, nobles y clérigos difunden el culto a la Vera Cruz en los países de la Corona de Aragón. Y en la España de los Reyes Católicos aumenta esa tendencia. El arzobispado de Toledo tuvo mucho que ver en la promoción del culto a la Vera Cruz en los reinos hispánicos en los siglos XV y XVI. Me refiero a la figura clave del arzobispo Pedro González de Mendoza (1428-1495), hijo del marqués de Santillana y cardenal desde 1478 adscrito precisamente a la iglesia romana de la Santa Cruz de Jerusalén. La vinculación de su propia imagen a la historia de la invención de la Santa Cruz fue constante desde entonces con atención particular a Santa Elena por ser la descubridora de la Vera Cruz enterrada en el Gólgota. Entre otras cosas, además de ser fundador del Colegio Mayor de la Santa Cruz de Valladolid, en su testamento determinó la fundación de un hospital en Toledo que debería estar asimismo bajo la advocación de la Santa Cruz, y al cual nombró su heredero universal. Su capilla funeraria en la catedral toledana se dedicó a Santa Elena e, incluso, su famoso terno de terciopelo labrado estuvo dedicado en su parte más importante, el capillo, al descubrimiento de la Santa Cruz. Además, en el bordado de dicho capilo la figura de Santa Elena recuerda algunos de los retratos de la reina Isa-

\footnotetext{
${ }^{24}$ SANT VICENT FERRER, Sermons, edición de G. Schib, vol. III, Barcelona, Barcino, 1975, sermón núm. XC, pp. 297-306.

${ }^{25}$ SANT VICENT FERRER, Sermons, edición de G. Schib, vol. VI, Barcelona, Barcino, 1988, sermón núm. CCIII, pp. 93-95.

${ }^{26}$ Carta citada por A. MUÑoz FERnÁndeZ, Las cofradías de la Vera Cruz en Castilla la Nueva. Siglos XV-XVIII en J. Sánchez Herrero (dir.), Las cofradías de la Santa Vera Cruz, citado, pp. 183-205, en concreto p. 194.
} 
bel la Católica, de quien el cardenal fue gran colaborador, a modo de identificación de la reina con la santa emperatriz ${ }^{27}$.

Caso parecido al del cardenal Mendoza, muy devoto de la Santa Cruz, es el de Francisco de Quiñones (1475-1540), general de los franciscanos y también cardenal del título de la Santa Cruz de Jerusalén en Roma. Este cardenal en 1536 obtuvo del papa Paulo III indulgencias para todos aquellos miembros de cofradías de disciplinados de la Santa Cruz que peregrinasen a Roma por la memoria de la Pasión de Cristo y su derramada sangre en la redención de los pecados. Un traslado de ese documento en que se concedían dichas indulgencias fue realizado años más tarde, en 1570, por el escribano de la cofradía de la Vera Cruz de Toledo a petición de la cofradía de la Vera Cruz de Requena, fundada hacia 1560. Según José Antonio Díaz, dichas indulgencias y las prácticas generales de culto, disciplina y procesión habían sido adoptadas antes tanto en la cofradía toledana como en la cofradía de la Vera Cruz de la ciudad de Valencia, tal y como se puede ver en el capítulo segundo de las constituciones primitivas de la misma, conservadas originales en su archivo ${ }^{28}$.

\section{El SANTO GRIAL, LOS CORPORALES, LA FIESTA DEL CORPUS CHRISTI, LOS DISCIPLINANTES Y LA SANGRE DE CRISTO}

La santa Sangre de Cristo que existía en Brujas en la segunda mitad del siglo XIII constituye el ejemplo más antiguo que conocemos en Europa sobre el éxito de este tipo concreto de reliquias, hasta el punto de que fue solemnemente reconocida por la Santa Sede en 1310 y dio lugar a una procesión anual el 3 de mayo, la festividad de la Invención de la Cruz. El relato de la leyenda, creado en 1380, cuenta que Thierry de Alsacia, conde de Flandes, tras su participación en la segunda cruzada de 1147-1149, habría recibido de Balduino III, rey de Jerusalén, la preciosa reliquia de la Sangre de Cristo que trajo a Brujas y ofreció a los vecinos de la ciudad. En cambio, la Sangre de Cristo aparece en un inventario de reliquias que se conservaban en Constantinopla en 1150. Su traslado de Oriente a Occidente debió de ocurrir después del saqueo de dicha ciudad por los cruzados latinos en 1204. Se sabe que el nuevo emperador Balduino donó a su hija Juana, condesa de Flandes, diversas reliquias de la Pasión y de la Sangre de

\footnotetext{
${ }^{27}$ Sobre la capilla funeraria, el terno o en general la personalidad del cardenal Mendoza véase el reciente catálogo de la exposición Ysabel, la reina católica. Una mirada desde la catedral primada, Arzobispado de Toledo, 2005, pp. 287 y siguientes.

${ }^{28}$ J.A. DÍAZ DE MARTínEZ, Historia de la venerable cofradía de la Vera-Cruz o Sangre de Cristo Señor Nuestro fundada en el templo del Carmen de la ciudad de Requena, Requena, Imprenta de Benito Huerta, 1850 (edición facsimilar de Librerías París-Valencia, Valencia, 1992). El texto del traslado documental de las indulgencias obtenidas por el cardenal Quiñones en nota 33 (pp. 26-31) y la referencia a las constituciones primitivas de la cofradía de la Vera Cruz de Valencia en nota 34 (p. 32).
} 
Cristo y, en concreto, el primer documento que cita la presencia de dicha reliquia en Brujas es de 1270. La existencia de la cofradía de la Santa Sangre de Brujas, la más antigua de Europa que se conozca bajo esta advocación, aparece mencionada por primera vez en 1405 y de ella formaban parte las principales familias de la oligarquía local. Las ordenanzas de 1449 constituyen el acta fundacional de esta cofradía en cuyo preámbulo se alude, sin embargo, a la existencia de estatutos anteriores que los cofrades no observaban adecuadamente. Dicha cofradía estaba dedicada a custodiar la reliquia de la Sangre de Cristo fundamentalmente con una motivación política clara, crear un mito nacional para las gentes de Flandes. Vista así, esta cofradía de la Santa Sangre de Brujas difiere profundamente de aquellas cofradías que nacieron a finales del siglo XIV bajo la advocación de la Vera Cruz y de la Pasión de Cristo, no siendo tampoco acompañada nunca por procesiones de penitentes o flagelantes. Por el contrario, sí que se vinculó desde su origen al culto de la Santa Cruz por la procesión que se hacía la fiesta de la Invención ${ }^{29}$.

El culto a la Preciosa Sangre, bajo diferentes formas devocionales y artísticas, experimentó un auge considerable durante los siglos XIV y XV. Observo en los países de la Corona de Aragón al menos cinco fenómenos distintos que promueven juntos el culto a la Sangre de Cristo en la Edad Media con anterioridad a la fundación de las primeras cofradías que ostentarán esta advocación a partir del siglo XVI. El primero de esos cinco fenómenos es el culto al Santo Grial en tierras de Aragón y Valencia. El Santo Cáliz, la más notable reliquia de la catedral de Valencia, es el que, según una tradición medieval, usó Jesucristo en la última cena con sus discípulos. Recordemos cómo el Evangelio apócrifo de Nicodemus cuenta que José de Arimatea recogió la sangre de Cristo crucificado que caía de la herida producida por la lanza de Longinos en su costado con el cáliz de la última cena. Este Santo Grial posteriormente fue trasladado por San Pedro a Roma, hasta que San Lorenzo lo envió a Huesca (la vieja Osca romana), su ciudad natal, para protegerlo del emperador Valeriano, quien había decapitado al papa Sixto II. San Lorenzo fue el diácono del papa encargado de salvar los tesoros de la Iglesia justo antes de morir en el martirio (año 258). De la ciudad de Huesca pasó al monasterio de San Juan de la Peña (se entiende que a un eremitorio mozárabe anterior a la fundación del monasterio entre los siglos IX-X) al producirse la invasión musulmana (año 713), y de allí lo llevó el rey Martín I a su capilla real en el palacio de la Aljafería de Zaragoza (año 1399), hasta que el rey Juan de Navarra el año 1437, en nombre de su hermano Alfonso V de Aragón, lo entregase al tesoro de la catedral de Valencia (donde hoy se conserva) junto con la Vera Cruz y otras reliquias pertenecientes a la corona ${ }^{30}$.

${ }^{29}$ A. RuCQuoI, La cofradía de la Santa Sangre de Brujas en J. Sánchez Herrero (dir.), Las cofradías de la Santa Vera Cruz, citado, pp. 277-286.

${ }^{30}$ A. BELtrán, Estudio sobre el Santo Cáliz, citado, p. 80. 
La leyenda del Santo Grial como el redescubrimiento de la Vera Cruz tiene mucho que ver con el ambiente espiritual generado entre nobles y clérigos a raíz de las Cruzadas a Tierra Santa. De todos los romances sobre el Grial, tal vez el más famoso sea Parzival, compuesto entre 1195 y 1216 por un caballero de origen bávaro llamado Wolfram von Eschenbach. En el principio de su obra este autor afirma que la versión de la historia sobre el Grial que escribió Chrétien de Troyes hacia 1188 con el título Le roman de Perceval o Le conte del Graal estaba equivocada. La suya era la correcta porque se basaba en una información privilegiada que obtuvo de un tal Kyot de Provenza, el cual encontró en Toledo la primera fuente de esta leyenda, redactada en escritura pagana. La versión original parece haber llegado a Europa occidental desde el otro lado de los Pirineos, es decir, desde al-Andalus. Discernir lo que es historia de lo que es leyenda en estos casos es entrar en un debate sin fín. Me interesa más saber quién difundió la leyenda y con qué objetivos, mucho más que entrar en la veracidad o no de lo que dice, sobre todo si no hay documentación que pueda confirmar algo al respecto. ¿Quién está detras de la tradición del culto al Santo Grial en Aragón y Valencia? ¿Cómo se manifiesta la relación entre ese culto al Santo Grial y la devoción a la Sangre de Cristo? ¿Dónde está el punto de enlace?

Lo cierto es que, al día de hoy, existe un documento de noviembre de 1135 referente a la concesión que hizo el rey Ramiro II de Aragón al monasterio de San Juan de la Peña de una serie de tierras en compensación por recibir diversas cosas de los monjes, entre ellas un cáliz de piedra preciosa (calice de lapide precioso) ${ }^{31}$. Esta noticia sólo constata pues la existencia de cierta copa valiosa que estaba en el monasterio en el siglo XII y el interés que tuvo el rey por poseerlo. Sin embargo, creo que el documento clave donde se plasma la promoción y legitimación oficial de la leyenda es el de septiembre de 1399 en que el rey Martín I manifiesta su enorme deseo de tener en su capilla real el cáliz de piedra de San Juan de la Peña en el cual nuestro Señor Jesucristo, en la Santa Cena, consagró su preciosa sangre, y que el bienaventurado Lorenzo, que lo recibió de San Sixto, lo envió con una carta suya al monasterio: desideraret et afectaret multum habere in Capella sua illum Calicem
lapideum cum quo dominus noster Iesus Christus in sua sancta cena
sanguinem suum preciossisimum consecravit et quem beatus Laurencius
qui ipsum habuit a sancto Sisto existente summo pontifice cuius discipu-
lus erat ac diaconus sancte Marie in dominica misit et dedit cum eius
litera Monasterio et conventui santi Johannis de la Penya sito in monta-
neis Jacce Regni Aragonum ${ }^{32}$.

\footnotetext{
${ }^{31}$ Ibídem, p. 41 y lámina I.

${ }^{32}$ Ibídem, pp. 44-47.
} 
Se ve claramente, por consiguiente, que es el propio rey Martín I quien refrenda con sus palabras en un documento oficial el culto al Santo Grial recogiendo una leyenda cuyos promotores anteriores todavía desconocemos. Ahora bien, hay un segundo detalle que no debemos dejar que pase por alto. Cuando a la muerte del rey Martín I en 1410 se hace inventario de los bienes muebles que el monarca tenía en su palacio real de Barcelona, aparece descrito allí ese cáliz de calcedonia el cual segons se diu fo aquell $a b$ que Jhesu Christ consagrà la sua sancta e preciosa sanch lo dijous sant de la Cena ${ }^{33}$. El caliz había pasado del palacio real de Zaragoza al de Barcelona. Más aún, en el documento del 18 de marzo de 1437 referente al depósito de las reliquias reales en la catedral de Valencia, la primera pieza del listado que se entrega es la Vera Cruz como ya dije, la segunda es lo calzer hon Jhesus Christ consagrà lo sanguis lo dijous de la cena, y la tercera, siguiendo el orden del inventario, es ni más ni menos que:

\begin{abstract}
un canó de crestal sedat dins lo qual ha del sanguis de aquell prevere que en les parts de Aragó administra la sua missa de vin blanch e com hac consagrat lo cors preciós de Jhesús Christ en lo sumint dubta per occasió del dit vin blanch valgués la dita consagració e per miracle de nostre Senyor Déu permès que lo dit vin blanch se convertí en sanch pura de Jhesús Christ. Et cubert lo dit canó d'or brodat ab letres de perles menu54des que dien Sanguis Jhesus Christi. Et guarnint lo dit canó axí al cap com al peu d'or ab pedres e perles, ço és, en lo peu dos çafiç e dos petres balaxes e tretze perles entorn del dit peu quasi com apòstols e al cap tres çafiç e dos balaxos engastats e dehuyt perles semblants....34.
\end{abstract}

Es decir, van juntos el Santo Grial y un tubo o ampolla con la Sangre de Cristo aparecida en el contexto de un milagro de los llamados de la Santa Duda. Este tipo de milagros acontecen según la tradición a los presbíteros que no creen o que les habita cierta incredulidad sobre la transubstanciación del vino en sangre cuando celebran la eucaristía y milagrosamente ésta se produce al aparecer la mismísima Sangre de Cristo en el cáliz. Entre estos milagros de tradición medieval en la Corona de Aragón destaca el del llamado Sant Dubte d'Ivorra en Lérida, que aconteció en el siglo XI supuestamente aunque su veneración sólo está documentada desde 1426. En suma, en el Grial hay Sangre de Cristo. La Vera Cruz, el Santo Grial y la Sangre de Cristo constituyen tres reliquias íntimamente relacionadas entre sí. Hacia finales del siglo XIV y principios del siglo XV así lo demuestra el quehacer de la propia monarquía aragonesa cuando las transmite a la catedral de Valencia inseparablemente porque las tres convergen en el mismo culto a la Santa Cruz y a la Pasión de Cristo.

\footnotetext{
${ }^{33}$ J. MASSÓ TORRENTS, Inventari dels bens mobles del Rey Martí d'Aragó en "Revue Hispanique", XII (1905), pp. 513-590, en concreto p. 569.

${ }^{34}$ A. BELTRÁn, Estudio sobre el Santo Cáliz..., citado, lámina III. La transcripción es nuestra porque el autor sólo ha utilizado y transcrito exclusivamente la descripción del cáliz que figura en segundo lugar del inventario de estas reliquias reales.
} 
El segundo fenómeno que quiero reseñar en convergencia con el anterior es la devoción popular al milagro de los Corporales, las hostias que sangran. Al respecto, José Luis Corral ha estudiado con sumo detalle uno de los casos más importantes acontecidos en los reinos peninsulares durante la Edad Media, el de los Corporales de Daroca ${ }^{35}$. Según la tradición ocurrió cerca de Llutxent el 23 de febrero de 1239, tras la conquista de Valencia por las tropas de Jaime I. Seis hostias consagradas en la celebración de la eucaristía quedaron empapadas en sangre dentro del paño que las cubría. Ante la pugna que se produce entre los clérigos por custodiar el paño ensangrentato, es una mula por sí sola, sin guiarla nadie, la que las trasladó hasta la iglesia de Daroca. Sin embargo, durante todo el siglo XIII la relevancia de este acontecimiento fue escasa, incluso en Daroca. La primera noticia documentada haciendo mención a este hecho es de 1276. Pero desde mediados del siglo XIV, a causa del auge que había adquirido en toda Europa la celebración de la fiesta del Corpus Christi, comenzaron a afluir a Daroca muchos peregrinos. Los papas concedieron privilegios e indulgencias, y la iglesia de Santa María de Daroca, depositaria de los Corporales, fue elevada a la categoría de colegiata. La procesión del Corpus se convirtió en el acto esencial de la fiesta y la fama de los Corporales potenció la identidad de Daroca como pueblo privilegiado por Dios, como ocurrió en Brujas con la reliquia de la Sangre de Cristo. La oligarquía urbana y el alto clero aunaron sus esfuerzos para que la presencia de los Corporales significara una especial relevancia para Daroca entre las demás ciudades, como reza el escudo de la población: "No se hizo nada semejante con ningún otro pueblo". Y la propagación del culto a la sangre y al cuerpo de Cristo provocó que surgieran en otros lugares milagros semejantes en torno al misterio de la eucaristía sobre todo a partir del siglo XIV: Ivorra, Sant Cugat del Vallès, Sant Joan de les Abadesses, Alboraya, Torreblanca, Alicante.

El tercer fenómeno corre paralelo al anterior. La bula otorgada en 1264 por Urbano IV institucionalizó la fiesta del Corpus Christi aunque tuvo escaso eco en las iglesias de la cristiandad. Sólo la potente maquinaria administrativa y burocrática creada por el papado aviñonés supuso la generalización de la fiesta desde el corazón de Europa hacia la periferia (Lieja 1246, Aviñón 1264, Colonia 1279, París 1323, Génova 1325, Roma 1350, etc.). Las ciudades y las iglesias de los reinos ibéricos también respondieron a la demanda popular que quería ver de cerca la sagrada forma del cuerpo de Cristo, exhibida en procesión cívica con la participación de toda la sociedad. El estudio sistemático que Rafael Narbona ${ }^{36}$ ha realizado sobre

${ }^{35}$ J.L. CORRAL LAFUENTE, Una Jerusalén en el Occidente medieval: la ciudad de Daroca y el milagro de los Corporales en "Aragón en la Edad Media", XII (1995), pp. 61-122.

${ }^{36} \mathrm{R}$. NARBONA VIZCAÍNO, Los juegos y espectáculos de la fiesta del Corpus Christi en los reinos ibéricos (1264-1545) en el libro del mismo autor titulado Memorias de la Ciudad. Ceremonias, creencias y costumbres en la historia de Valencia, Ayuntamiento de Valencia, 2003, pp. 131-162. 
este tema confirma que las más antiguas procesiones celebradas en España fueron las de Toledo (1280) y Sevilla (1282). En los países de la Corona de Aragón el momento culminante del origen de las principales procesiones conocidas es el siglo XIV: Gerona (1314), Barcelona (1319-1323), Tarragona (1320), Valencia (1326), Lérida (antes de 1340) o Mallorca (1371). En Zaragoza se ha podido documentar esta procesión desde $1423^{37}$.

El cuarto fenómeno que concurre en la difusión múltiple del culto al cuerpo y a la sangre de Jesucristo es, sin lugar a dudas, el auge del ritual público de los penitentes y disciplinantes. Uno de los principales difusores de estas prácticas fue San Vicente Ferrer con sus sermones. Para empezar, en las palabras que pronunciaba el día de la festividad de san Lorenzo, san Vicente difundía el culto al Santo Grial (Sent Lorenç dave del sanguis ab lo calze plen de la sanch de Jesuchrist, lo qual havie consagrat lo papa) y a los Corporales (e per ço com ja en la òstia ha carn e sanch, car en tot cors viu ha carn e sanch $)^{38}$. Promovía el ejemplo de Jesucristo en clave de penitencia: Ara, bona gent, apparellau-vos tots de crucificar. Benaventurat serà qui crucificat será ${ }^{39}$. Sus predicaciones en tiempo de Cuaresma merecen especial atención por la promoción que hace de las prácticas disciplinantes y el culto al derramamiento colectivo de sangre. Un listado de frases significativas de San Vicente en sus sermones no deja lugar a dudas:

\begin{abstract}
Nostre Senyor Déu me ha remut ab la sua passió, me ha comprat ab lo seu preciós sang ${ }^{40}$. És una preciosa cosa lo assotar de les disciplines, majorment a homeiers, que a aquells los és pus propri escampar la sua sang $^{41}$. Volgué ésser pres e lligat e crucificat, per reembre a nosaltres; e açò és exemple a nosaltres quan fem penitència escampant sang per honor e remembrança de la passió de Jesucrist, "Semper mortificationem corporis" $(2 \mathrm{C}, 4,10)$; portem en lo cor la passión ${ }^{42}$. E si ell volc tanta aflicció al cos, ¿què devem fer nosaltres? "Semper mortificationem" $(2 \mathrm{C}, 4,10)$; e portem-nos quecom de penitència ${ }^{43}$.
\end{abstract}

A partir de aquí creo que procede estudiar los itinerarios seguidos por San Vicente y la relación que existió entre sus sermones en diversas poblaciones de la Corona de Aragón y la aparición de movimientos disciplinantes que servirían de modelo precedente para las procesiones de los cofrades de

\footnotetext{
${ }^{37}$ M.I. FALCÓN PÉREZ, La festividad del Corpus Christi en los pueblos de Aragón en la Edad Media y La procesión del Corpus en Zaragoza en el siglo XV en Estado actual de los estudios sobre Aragón, Actas de las V Jornadas (Zaragoza, diciembre 1982), Zaragoza, 1984, pp. 625-632 y 633-638 respectivamente. 66.

${ }^{38}$ SANT VICENT FERRER, Sermons, vol. III, citado, sermón núm. LXIII, en concreto p.

${ }^{39}$ Ibídem, p. 264.

${ }^{40}$ SANT Vicent Ferrer, Sermons de Quaresma, 2 vols., Valencia, Albatros Edicions, 1973, vol. I, p. 51.

${ }^{41}$ Ibídem, vol. I, p. 153.

${ }^{42}$ Ibídem, vol. I, p. 188.

${ }^{43}$ Ibídem, vol. II, p. 92.
} 
la Vera Cruz o de la Sangre de Cristo. Luego comentaré el caso de los ciegos oracioneros de Valencia y su cofradía de la Vera Cruz.

Por último, el quinto fenómeno convergente es el culto directo a la Sangre de Cristo. El tratado de Domenico Cavalca que poseía en su biblioteca la reina María de Castilla en el siglo XV promovía, como hacían otros tratadistas de su época, la imagen de la Santa Cruz sangrante en algunos de sus pasajes:

Longí, lo qual era quasi orb, segons que dien alguns sants, haven ferit ab colp de lança e ubert lo costat de Jesucrist, per l'asta de la lança devallà aygua sanch qui n'hixia habundantment e tocà la mà del dit Longí, e aquell per cas fregà's los ulls ab aquella mà sangonosa, e sobtosament fou il·luminat, no tant solament en lo cors, mas encara en la ànima ${ }^{44}$.

Según Cavalca, Jesucristo escampó su sangre siete veces por nosotros durante su vida: 1) la circuncisión; 2) sudando gotas de sangre en el huerto de los Olivos; 3) flagelado y azotado en la columna; 4) coronado de espinas; 5) cuando le clavaron las manos en la cruz; 6) cuando le clavaron los pies; y 7) cuando Longinos le clavó la lanza en el costado. El dominico concluye al respecto: Donchs, appar que de tot lo cors volgué fer la sagnia per guarir tot lo cors de la Sglésia. Es decir, Cristo en su pasión hizo un baño de sangre y de agua completo para lavar todos los pecados de la humanidad ${ }^{45}$.

En la diócesis de Valencia, la devoción a la Sangre de Cristo cobra más importancia a partir de 1460 con la reforma del breviario valentino de Rodrigo de Borja, obispo de Valencia, institucionalizándose definitivamente el 19 de junio la fiesta de la Preciosísima Sangre de Cristo, según recogen César Jordá y Vicent Pons ${ }^{46}$. En 1521, Andreu Martí Pineda publicaba una obra dedicada a exaltar las excelencias de la Sangre de Cristo ilustrada con grabados alusivos a esos siete momentos en los que Jesús había derramado su preciosa sangre ${ }^{47}$. Además, existió una afinidad directa entre las artes figurativas y la literatura religiosas en la Valencia del tránsito del siglo XV al XVI a la hora de exaltar con todo su patetismo la muerte de Cristo en la cruz y ponderar hasta el infinito las virtudes de su sangre derramada $^{48}$.

${ }^{44}$ D. Cavalca, Mirall de la Creu, citado, vol. II, p. 19.

${ }^{45}$ Ibídem, pp. 77-78.

${ }^{46}$ C. JORDÁ SÁNCHEZ y V. PONS Alós, Las cofradías de la Vera Cruz y Sangre en la Diócesis de Valencia: la transición de la religiosidad medieval a la moderna en las cofradías de Xàtiva en J. Sánchez Herrero (dir.), Las cofradías de la Santa Vera Cruz, citado, pp. 773 796, concretamente p. 778, nota 24.

${ }^{47}$ A.M. PINEDA, Contemplacio en Honor y Reverencia de les sets vegades quel Nostre Redemptor Jesus escampa la sua Preciosissima Sanch ab les propietats de cascuna feta, Valencia, Joan Jofre, 1521 .

${ }^{48}$ M. FALOMIR FAus, Arte en Valencia, 1472-1522, Valencia, Consell Valencià de Cultura, 1996, pp. 346 y siguientes. 


\section{LAS COFRADÍAS DE LA VERA CRUZ DESDE EL SIGLO XIV: XÀTIVA, VALENCIA, ZARAGOZA Y REQUENA}

Las cofradías actuales, sean de la advocación que sean, están obsesionadas por ser las más antiguas en su género. A veces sus cronistas proclaman orígenes medievales donde no los hubo y se apuntan fechas fundacionales que no están documentadas. El historiador profesional que se acerca a estas instituciones para estudiar su pasado debe comenzar por desmitificarlo, separando lo que está inventado de lo que está documentado. Hoy por hoy, a falta de más investigaciones, sólo conozco cuatro cofradías de la Vera Cruz documentadas en los países de la Corona de Aragón. La más antigua de todas, sin que esto para mí signifique ningún factor de relevancia especial, salvo que hubiese servido de modelo a otras cofradías posteriores bajo la misma advocación o en su contexto local, es la de la Vera Cruz de Xàtiva. Sólo un artículo se ha hecho eco de manera monográfica de aquellas ordenanzas que publicó Manuel de Bofarull y de Sartorio en 1876 , aunque se centra principalmente en cuestiones lingüísticas ${ }^{49}$. El documento referido no es el acta fundacional de la cofradía sino una segunda confirmación posterior a cargo de Pedro IV, fechada en Zaragoza el 25 de octubre de 1381. Esta entidad se creó por un privilegio de la reina Leonor de Castilla, a la que ya he aludido con anterioridad, otorgado en la ciudad de Zaragoza el 21 de octubre de 1333. En esa fecha ella era la señora natural de Xàtiva por donación que de ésta le hizo su marido Alfonso IV de Aragón. Y como se indica en el prefacio del documento, el 27 de abril de 1339 dichos capítulos fueron confirmados por primera vez a cargo de su sucesor, el rey Pedro IV, en una carta suya dada en Valencia.

La reina Leonor de Castilla, en calidad de señora feudal de Xàtiva, instituye una cofradía bajo la invocación de Nuestro Señor Jesucristo, la Virgen María y la Santa Vera Cruz con el objetivo de que en ella se hagan penitencias, limosnas y obras de caridad y de misericordia. Entre 1333 y 1381 dicha cofradía fue dotada de muchos otros singulares privilegios, gracias, inmunidades, indulgencias y favores por parte tanto de la monarquía como de la iglesia. Desconocemos cuáles fueron aunque en el texto de las ordenanzas se citan algunos como luego diré. Lo cierto es que la solicitud de nuevas ordenanzas en 1381 parte de ciertos prohombres y personas de la ciudad de Xàtiva que son cofrades, encabezados por Bartomeu March que era notario y ciudadano de la población. Considerando la especial devoción que siente el rey Pedro IV por la Santa Cruz y queriéndolo imitar en esa creencia, los prohombres ordenan de nuevo la cofradía.

\footnotetext{
${ }^{49}$ M. DE Bofarull y DE SARTORIO, Colección de Documentos Inéditos del Archivo General de la Corona de Aragón, Barcelona, 1876, doc. XLVIII, pp. 205-234. Veáse A. VENTURA CONEJERO, Ordinacions de la confraria de la Vera Creu de Xàtiva: introducció i comentaris en "Papers de la Costera", 5 (1987), pp. 213-225.
} 
El rey de Aragón es el cofrade mayor junto a la reina, el duque de Gandia, los infantes, el obispo de Valencia, el arcediano y el vicario de la iglesia de Xàtiva, y todos los frailes predicadores y franciscanos de los conventos de la ciudad (cap. III). Los otros cofrades de la hermandad son 200 legos entre caballeros, generosos y ciudadanos; 200 cofradesas viudas, sin contar las mujeres de los legos que serán también cofradesas por serlo sus maridos; y 50 presbíteros del clero secular (cap. IV). A lo largo de los 65 capítulos que componen estas ordenanzas se expresa con precisión todas y cada una de las actividades que caracterizan a la cofradía bajo la dirección del prior y los mayorales. Del conjunto quiero destacar que, a reverencia de Jesucristo bajo cuyo nombre la cofradía es intitulada, cofrades y cofradesas acompañarán el cuerpo precioso del Señor en la procesión con sus cirios en la mano el día de Corpus Christi (cap. XXXI). Se menciona también una licencia real dada en Almenara el 11 de mayo de 1375 sobre las ejecuciones de pias causas de la cofradía que podían llevar a cabo sus mensajeros (caps. XLIIII y LXIII). Existía un libro padrón a cargo del escribano desde que el citado notario Bartomeu March fue regidor del mismo y prior de la cofradía en 1376 (cap. LXI). Consta asimismo otro privilegio real dado en Zaragoza el 7 de octubre de 1347 en el que se donaba para mantenimiento de la cofradía una renta censal anual de 1.000 sueldos cargada sobre el realengo, aunque en 1381, año de la reforma de las ordenanzas, la cofradía no percibía sino 650 sueldos de renta anuales, poco más o menos, que procedían de las casas, posesiones, campos, viñas, huertos, tierras censales y otras propiedades que tenía dicha entidad desde su fundación (cap. LXIIII). De forma complementaria, en el Archivo Diocesano de Valencia se conserva un litigio entre el prior de la cofradía y la persona que debía ceder la capilla en la iglesia de Xàtiva para los actos religiosos. Parece ser que, al principio, tenía como sede el convento de Predicadores pero en el siglo XVI estaba ubicada en la iglesia colegial, según muestra una concordia del 22 de mayo de 1570 entre el cabildo y la cofradía, localizada en el archivo municipal, en la cual se concedía entre otras cosas a dichos cofrades y cofradesas un lugar privilegiado en la procesión del Corpus Christi $^{50}$.

La Vera Cruz de Xàtiva no es la única cofradía de esta advocación que existía en el reino de Valencia. Manuel Benítez ha puesto de manifiesto el caso de la cofradía de ciegos de Valencia que en las ordenanzas del año 1329 aparecía bajo el título de la Virgen María, mientras que en los capítulos solicitados en el año 1407 se encontraba bajo el signo de la Vera Cruz. En estos mismos capítulos se solicitaba cambiar la fiesta anual de la cofradía que era los octavos de Pascua florida a la fiesta de la Exaltación de la Cruz del 14 de septiembre. El autor ha encontrado hasta cuatro privilegios distintos de esta cofradía en la serie de registros de cancillería real del Ar-

${ }^{50}$ J. Bellver Blasco, Cofradía de la Purísima Sangre de Cristo y de Ntra. Sra. de la Soledad. Apuntes históricos, siglos XVI-XIX, Xàtiva, 2000, pp. 24-25. 
chivo de la Corona de Aragón. Los miembros de esta hermandad poseían una casa en la parroquia de la Santa Cruz para reunirse, comer y tener capítulo. Interesa resaltar que desde 1392 esta cofradía obtuvo licencia para comprar censales y otros bienes de realengo, con lo cual, una hermandad de ciegos pobres, de claro corte benéfico y asistencial, se irá convirtiendo poco a poco en una sociedad rentista ${ }^{51}$.

Lo cierto es que esta cofradía en sus orígenes, antes de adoptar la advocación de la Vera Cruz, ya celebraba su fiesta patronal en la iglesia parroquial de la Santa Cruz de la ciudad de Valencia. Esta circunstancia se mantuvo así desde 1329 hasta 1610 por lo menos, a tenor de la relación que se hizo ese año sobre el estado de la diócesis valenciana y que, al hablar de la citada iglesia de la Santa Cruz, explica que en ella hay una cofradía de ciegos que tiene casa y capilla en la cual se dice misa, con sus constituciones visitadas por el ordinario ${ }^{52}$. No resultaría extraño que los ciegos valencianos decidiesen cambiar su advocación a la Vera Cruz al escuchar los sermones de san Vicente Ferrer. Precisamente, en el sermón que predicaba el 14 de septiembre -festividad de la Exaltación de la Santa Cruz y fiesta patronal de la cofradía de ciegos- contaba cómo al principio la Santa Vera Cruz era menospreciada por los infieles, pero después fue muy honrada, sobre todo por los muchos milagros que acontecieron con ella, entre otras cosas porque iluminaba a los ciegos (que il luminava los cechs) ${ }^{53}$. ¿Promovió san Vicente Ferrer conscientemente el cambio de advocación de esta cofradía? ¿Si no de quién partió la iniciativa? ¿Es esta cofradía de ciegos de la Vera Cruz de Valencia la que se cita en 1570 en un documento de Requena? ${ }^{54}$ Desde luego, la relación de la diócesis de Valencia de 1610 no nombra otra con esa advocación en la ciudad.

En Zaragoza se ha documentado en 1360 la presencia de una cofradía de la Santa Cruz adscrita a la iglesia parroquial del mismo título. En la parroquia de Santa Engracia en 1394 también existía una cofradía de la Crucifixión del Señor y Santa María ${ }^{55}$. Sin embargo, fray Roque Alberto Faci da una noticia importantísima sobre la existencia de una cofradía de la Vera Cruz distinta a las anteriores al hablar de las reliquias de la Santa Cruz que se conservaban en el Aragón de su época. La primera reliquia que cita es la que se veneraba en el convento del Carmen de Zaragoza, una preciosísima porción del Lignum Crucis regalada junto con otras reliquias

\footnotetext{
${ }^{51} \mathrm{M}$. Benítez Bolorinos, Las cofradías medievales en el Reino de Valencia (13291458), Universidad de Alicante, 1998, pp. 29, 45 y 137.

${ }^{52}$ Ibídem, p. 154. Véase Relaciones sobre el estado de las diócesis valencianas, edición a cargo de M. M. Cárcel y V. Cárcel, Valencia, Generalitat Valenciana, 1989, tomo II (Valencia), p. 739 .

${ }^{53}$ SANT ViCENT FERRER, Sermons, vol. III, citado, p. 297.

${ }^{54}$ Véase nota 29 supra.

${ }^{55}$ A. DEL CAMPO GUTIÉRREZ, Aproximación a un mapa devocional de Zaragoza en el siglo XIV en "Turiaso. Revista del Centro de Estudios Turiasonenses", XVI (2001-2002), pp. $87-143$, en concreto pp. 115 y 140.
} 
por la reina doña María, esposa de Alfonso V el Magnánimo. La reina fue benefactora del convento y llegó a celebrar en su edificio las cortes de 1441:

A devocion, y con titulo de esta Santisima Reliquia se fundo en dicho Convento la Antigua Cofadria de la Santa Vera Cruz, y se hacia Procession de la disciplina, cuyos Cofadres eran los mas Nobles de Zaragoza: consta de las memorias antiguas del Convento, y Bulas de la Cofadria, y lo noto todo el Padre Murillo, en las Excelencias de Zaragoza ${ }^{56}$.

La fecha de la entrega es de 1450 según documenta como testigo ocular el mismo padre Faci, puesto que la reliquia fue entregada por la reina al convento engastada en una cruz grande de plata sobredorada que en el año 1652 fue restaurada, y que el 21 de abril de 1724 él mismo pudo ver la inscripción que contenía debajo del pie de dicha cruz:

dona fuere huic. Fac. Car. Caenob. Pro amor. Pigno. Mag. A. REgina ARAGO. MARIA, ALFON. REG. SPON. ANNO 1450.

Según Faci, la cofradía de la Vera Cruz de Zaragoza celebraba sus fiestas el 3 de mayo y el 14 de septiembre con gran solemnidad, y quizás los excesos en gastos acabaron por consumir la hermandad y toda su grandeza. Las indulgencias papales que tenía concedidas eran muchas, comenzando por la bula de Paulo III de 1536 donde se dio indulgencia plenaria a todos los que tomasen disciplina de Sangre, instituida por san Vicente Ferrer en la Villa de Graus (cita textual de Faci) o alumbraran alguno de los pasos de la procesión. Toda la documentación de esta cofradía estaba, según dicho autor, en el archivo del convento. Mi investigación al respecto no ha hecho más que comenzar, teniendo en cuenta que, al menos, entre 1450 y 1536 esta hermandad existió y ha debido de dejar pruebas fehacientes de ello en algún sitio.

Sobre la cofradía de la Vera Cruz de Requena se ha escrito un breve ensayo de interpretación que pretende actualizar las monografías eruditas de José Antonio Díaz de Martínez ${ }^{57}$ y Rafael Bernabeu ${ }^{58}$. Dicho estudio sitúa aproximadamente la fecha de fundación de esta hermandad en 1560 en relación directa con la bula concedida por el papa Paulo III a los cofrades de la Vera Cruz de Toledo el año $1536^{59}$. Efectivamente, todo parece indicar que esa bula tuvo gran influencia en la aparición o consolidación de

${ }^{56}$ R.A. FACI, Aragon, reyno de Christo y dote de Maria Santissima, Zaragoza, 1739-1750, edición facsimilar a cargo de la Diputación General de Aragón, Zaragoza, 1979, tercera parte, pp. 28-29.

${ }^{57}$ J.A. DÍAZ DE MARTÍNEZ, Historia de la venerable cofradía de la Vera-Cruz..., citado.

${ }^{58} \mathrm{R}$. BERNABEU LÓPEZ, La Vera Cruz requenense. Efemérides, ceremonias, litigios, ordenaciones y curiosidades, Requena, Artes Gráficas Molina, 1955.

${ }^{59}$ C. JORDÁ SÁNCHEZ, La cofradía de la Vera Cruz de Requena en J. Sánchez Herrero (dir.), Las cofradías de la Santa Vera Cruz, citado, pp. 761-771. 
muchas cofradías similares en España, tal y como confirma la copia que la cofradía de Requena solicitó en 1570 a la de Toledo y a la que antes he aludido. Más noticias sobre este tipo de hermandades en la Corona de Aragón no tengo por el momento, aunque estoy estudiando cualquier noticia sobre hospitales, iglesias parroquiales o capillas dedicadas a la Santa Cruz para indagar sus posibles vinculaciones con actividades cofrades. Algunos ejemplos significativos pueden ser los hospitales de la Santa Cruz y San Pablo de Barcelona o el de la Santa Cruz de Tortosa, o los monasterios de Santa Cruz de la Serós en las cercanías de Jaca y el de Santes Creus en Tarragona.

\title{
5. LAS COFRAdÍAS DE LA SANGRE DE CRISTO DESDE EL SIGLO XVI: ZARAGOZA, CASTELLÓN, ALCOI, CULlERA Y OTRAS MUCHAS
}

El primer documento conservado sobre la hermandad de la Sangre de Cristo de Zaragoza data del 28 de octubre de 1554. Se trata de un acuerdo firmado en presencia del notario Juan Díaz de Altarriba con el convento de San Agustín para establecer allí la asistencia espiritual a los condenados a muerte. Fue transcrito y publicado por el profesor Ángel San Vicente y nunca ha sido estudiado con profundidad, teniendo en cuenta la información tan importante que contiene ${ }^{60}$. Para empezar, la concordia habla de la confraria nuebamente instituida en dicho monesterio llamada de la Sangre de Cristo. La expresión no deja claro si la cofradía se fundó antes en otro convento o iglesia. Lo cierto es que en un párrafo del acto notarial se lee:

\begin{abstract}
la principal causa y debocion que ha mobido a los dichos confrayres de la dicha confraria para ordenar la dicha Hermandat y Confraria de la Sangre de Jesuchristo es para consolar y ayudar a bien morir como catolicos cristianos a los condempnados y sentenciados a muerte en la dicha ciudad de Çaragoça, y ayudarles a bien morir y acompanyarles por las calles asta ser muertos, y porque esto no se puede bien hazer con legos sin que entrebengan religiosos e personas ecclesiasticas, asi para los confesar como para consolarlos y ayudarles a bien morir.
\end{abstract}

La hermandad existía, por tanto, antes de fijar este acuerdo. ¿Desde cuándo? ¿Hay referencias en testamentos del siglo XV a la actividad de esta cofradía?

En la práctica el acuerdo va mucho más allá de pedir simplemente la asistencia espiritual a los frailes de San Agustín. El convento da a los mayordomos y cofrades de la Sangre la capilla bulgarmente llamada del

\footnotetext{
${ }^{60}$ A. SAN VICENTE PINO, Instrumentos para una historia social y económica del trabajo en Zaragoza en los siglos XV a XVIII, Zaragoza, Real Sociedad Económica Aragonesa de Amigos del País, 1988, tomo I, doc. 145, pp. 275-278. Véase el breve análisis que ofrece sobre dicho documento la tesis de licenciatura de J.L. GóMEZ URDÁNEZ, La Hermandad de la Sangre de Cristo de Zaragoza. Caridad y ritual religioso en la ejecución de la pena de muerte, Zaragoza, Asociación para el Estudio de la Semana Santa, 2004 (reedición de la obra origi nal publicada por la Institución Fernando el Católico de Zaragoza en 1981).
} 
Crucifixo, sitiada en la claustra del dicho monesterio, para que los dichos confrayres puedan tener y tengan la invocacion de la dicha confraria en la dicha capilla. En ella tienen licencia además para enterrarse los cofrades y sus sucesores dende la primera grada de la dicha capilla todo el spacio de ancho y largo asta la paret frontera exceptado la sepultura de Ochoa de Marquina. Ahí celebrarán sus misas y las fiestas patronales. Cada año, el jueves santo por la noche, harán los cofrades una procesión de disciplinantes con la mayor devoción que puedan, acompañados de los frailes del convento. El itinerario viene registrado en el documento: saliendo de San Agustín irán a la Seo pasando por la casa de doña María Cariñena; de la Seo al Pilar y de aquí a San Antón y San Pablo; de San Pablo por la Cedacería y Coso arriba hasta San Francisco, el Hospital, San Gil, San Pedro; y al cabo de la calle volviendo por la Magdalena al dicho monasterio de San Agustín.

En el plazo de tres años a partir de la fecha de la concordia firmada, los cofrades quedan obligados a hazer hazer a sus costas un Crucifixo para llebar en la procesion de juebes sancto y otras procesiones de la quaresma. El encargo correrá a cargo de los dineros de la cofradía. El domingo de Cuaresma harán otra procesión de disciplinantes alrededor del dicho monasterio como lo han hecho algunos anyos para coger limosnas, a partir a medias entre la cofradía y el convento. Obsérvese cómo con anterioridad a este acuerdo de 1554 parece que la hermandad ya hacía procesiones en torno a San Agustín. Por añadidura, el convento entregaba también a disposición de los cofrades la cámara y patio de la librería que había dentro de la citada capilla del Crucifijo para que tuviesen un almario y archiu para tener las scripturas de la confraria y la bulla de las indulgencias. ¿Se refiere a la bula de Paulo III de 1536? ¿Ya existía entonces esta cofradía?

Los cofrades de la Sangre de Zaragoza quedaban obligados también a hacer a su costa una arca donde estarían guardadas las camisas y todos los aparejos para hacer la procesión de los disciplinantes. En caso de que se disolviera la hermandad, habría que restituir al dicho convento las veinticinco camisas de disciplinantes que éste había hecho ya a su cargo. Y en cuanto al acompañamiento de los condenados a muerte se realizaría desde la cárcel por las calles hasta que el sentenciado hubiese expirado con la mayor devoción pues con el cuerpo paga la deuda que por sus delitos meresce el alma con verdadera penitencia y contricion alcance la bienabenturança para la qual fue criada. Dos padres religiosos del convento irán con los cofrades para confesar y velar a los reos en la cárcel la noche antes de salir para que se cumpla la sentencia públicamente.

Por otra parte, las dimensiones que tiene la capilla del Crucifijo permiten acoger al prior y a los frailes del convento de San Agustín de Zaragoza para la firma del acuerdo, esto es, un total de once personas. Sin embargo, los honorables mayordomos y cofrades de la hermandad de la Sangre de Jesucristo por ser una cifra mayor de asistentes se reúnen en el refectorio mayor del dicho monasterio. Suman un total de 27 personas cuyos nombres paso a reproducir a continuación por orden alfabético, anotan- 
do en cursiva algunas hipótesis de trabajo sobre su identidad que proporcionan los listados onomásticos publicados o la documentación inédita disponible sobre el siglo XVI:

Bueris, Beltrán, maestre, sombrerero

Burgos, Bartolomé de

Burguñón, Juan, maestre, hijo del sastre del mismo nombre

Casanova, Bernardo, maestre

Castillo, Pedro

Caxo, Juan del, maestre, corredor de ropa

Cherte, Juan de

Coreta, Miguel

Espinosa, Juan de

Gan, Juan de, hijo del pelaire Arnau de Gan

Garnica, Martín de, padre del cirujano Juan de Garnica

Grez, Martín de

Lamata, Pedro, sastre

Lasmartes, Francisco, maestre

López, Miguel, bonetero

Madrigal, Felipe de

Martínez, Pedro, mayordomo, sombrerero

Murcia, Juan de, llamador, hijo del médico Nicolás de Murcia

Navarro, Agustín

Oña, Juan de

Palacio, Salvador, maestre

Ramos, Juan

Raya, Juan de la, mayordomo

Ricla, Jaime de, maestre, esgrimista

Romerales, Pedro

Vidal, Domingo

Xatel, Esteban

¿Quiénes son estas personas? ¿A qué perfiles sociales responden en la Zaragoza de mediados del siglo XVI? Por las hipótesis de trabajo que manejo se trata de gentes de la ciudad vinculadas a profesiones artesanales o del comercio (bonetero, corredor de ropa, sastre, sombrerero). No parece tratarse de una cofradía de nobles y clérigos al estilo de algunas de las que hemos hablado. Además, un siglo después de este documento, concretamente el 12 de mayo de 1648, la sede de la hermandad se trasladó al convento de San Francisco con un acuerdo similar al que en un principio se estableció con los frailes de San Agustín ${ }^{61}$. Tal vez por eso el padre Faci habla de la cofradía de la Sangre de Cristo y de la Madre de Dios de la Misericordia como una hermandad fundada en el convento de San Francisco

\footnotetext{
${ }^{61}$ J.L.GÓMEZ URDÁÑEZ, La Hermandad de la Sangre de Cristo, citado, p. 12.
} 
de Zaragoza, en el Coso, dedicada a dar caridad a los desamparados, así vivos como difuntos. Según relata este autor, tenía una espaciosa capilla que se veía en el atrio de la iglesia de dicho monasterio. Había en ella una imagen del Señor bajado de la cruz:

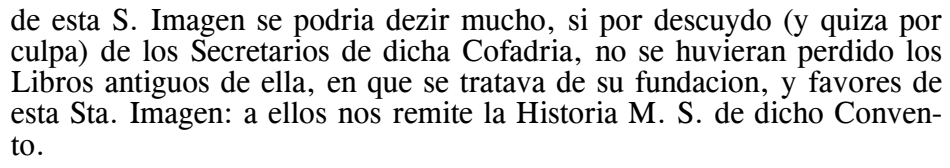
culpa) de los Secretarios de dicha Cofadria, no se huvieran perdido los Libros antiguos de ella, en que se tratava de su fundacion, y favores de esta Sta. Imagen: a ellos nos remite la Historia M. S. de dicho Convento.

Es el Santo Crucifijo del Descendimiento con el que se hacía procesión por el Coso el día de la Invención de la Cruz a cargo de dicha cofradía, repitiéndose la misma procesión en la festividad de la Exaltación. Hubo también en esta cofradía otra imagen denominada el Santo Cristo de la Cárcel con el que se acompañaba a los condenados a muerte ${ }^{62}$.

La cofradía de la Sacratísima Sangre de Jesucristo de Castellón de la Plana ya existía en 1549 y desde sus orígenes aparece vinculada a la asistencia hospitalaria. No se ha hallado documento alguno que nos hable de la actividad de esta cofradía antes de esa fecha ${ }^{63}$. En 1562 era clavario el notario Marc Arrufat y en la primera acta conocida de una junta de esta cofradía en el año 1565 figura como clavario el droguero Jaume Gombau y como mayorales el sastre Andrés de Dueñas y el labrador Andreu Lluch. El estudio sociológico de sus componentes a través de las bases de datos prosopográficas disponibles confirma la identidad ciudadana dominante protagonizada por profesiones liberales, oficios artesanales, pequeños comerciantes y labradores ${ }^{64}$. Ese año de 1565 las autoridades municipales concedieron a la cofradía diversas estancias del hospital de la villa, a saber, la capilla y el dormitorio de los pobres con ciertas cámaras y la cocina del dicho hospital. La cofradía correría con los gastos de la construcción de otra cocina y un apartamento para el hospitalero, así como un nuevo dormitorio. También poseía capilla propia desde 1572 en un rincón del claustro junto al huerto del convento de San Agustín y dos años antes se cita en un testamento como loable confraria de la Sanch de Jesuchrist de la Sglésia Major de dita vila.

La cofradía de la Sangre de Nuestro Redentor y Señor Jesucristo de la villa de Alcoi vio aprobados sus estatutos fundacionales el 27 de marzo de 1545 por el vicario general de Valencia. El texto con los cinco capítulos que contienen los citados estatutos ha sido publicado por la profesora Mila-

\footnotetext{
${ }^{62}$ R.A. FACI, Aragon, reyno de Christo, citado, primera parte, pp. 40-41.

${ }^{63}$ Continúa siendo fundamental el apéndice de documentos publicado por L. REVEST CORZO, El Hospital de Castellón y la Cofradía de la Sangre en "Boletín de la Sociedad Castellonense de Cultura", XX (1944), pp. 142-158 y 165-191.

${ }^{64}$ P. Iradiel Murugarren; D. Igual Luis; G. NAVARro Espinach; J. Aparici MarTí, Oficios artesanales y comercio en Castelló de la Plana (1371-1527), Castellón, Fundación Dảvalos-Fletcher, 1995 .
} 
gros Cárcel ${ }^{65}$ y nos permite extraer varios comentarios con vistas a establecer comparaciones con Zaragoza y Castellón. La hermandad nace destinada a acompanyar lo combregar dels confrares malalts, visitar y servir aquells qui seran pobres quant seran requests. Se concede licencia para que funden una capilla situada cerca del hospital de San Cristóbal en Alcoi y podrán formar parte de la cofradía qualsevol persones de qualsevol condició, honestes y de bona fama. Aunque más adelante se insiste en que ningún mayoral pueda ser converso ni amigado ni hombre de mala fama, sólo si es buena persona. Algo que, como es obvio, decidían los miembros de la junta según el sistema de valores imperante. La señal identitaria de la cofradía era un escudo blanco con las cinco llagas de Cristo (recuérdese las cinco misas por la devoción a las cinco llagas que se ordenan en muchos testamentos de la época). El acto central del calendario festivo en la casa que serviría de sede a la cofradía de Alcoi resultó ser, sin duda, specialment lo Dijous Sanct, per a que en aquella se ajuste lo prior ab tots los del ramat dels açotants de la confraria de la Sanch de Jesu Christ y en aquella tornats se puguen curar. De todos estos datos quiero destacar que la cofradía de Alcoi se concibe a diferencia de la de Zaragoza o Castellón como una entidad solidaria aparentemente sólo con sus propios asociados más desfavorecidos. No acompaña a los condenados a muerte. Otra diferencia notable es que aquí se alude a un emblema identitario del colectivo, aspecto que no se menciona en la documentación de las otras entidades. Sí que coincide claramente al menos con Zaragoza, a falta de los estatutos fundacionales de la de Castellón, en considerar el momento central del año la procesión de disciplinantes del Jueves Santo que, en Alcoi, se preve lo suficientemente dura y exacerbada como para aludir a la curación de los heridos que tiene lugar en la casa de la cofradía al terminar dicha procesión.

En el Archivo Diocesano de Valencia se encontraron también otros cinco capítulos fundacionales de la cofradía de la Sangre de Cullera del 9 de julio de 1546, aprobados asimismo por el vicario general de la sede valentina $^{66}$. La finalidad de la hermandad de Cullera es idéntica a la de Alcoi, creada un año antes. Acompañarán los cuerpos de los cofrades difuntos y ayudarán a los enfermos, visitando y sirviendo a los más pobres. Para sus fiestas dispondrán de la capilla de la Sangre del hospital de San Juan en Cullera y sólo podrán formar parte de la entidad personas honestas y de buena vida y fama. El oficio más solemne se celebrará en la misa de Circuncisión y Sangre de Jesucristo, y el acto central lo constituirá la procesión de disciplinantes del Jueves Santo. Finalmente, se alude a la señal de la cofradía pero no se especifica en qué consiste como sucede en Alcoi.

\footnotetext{
${ }^{65}$ M.M. CÁRCEL ORTí, Aportación al estudio de las cofradías valencianas del siglo XVI: la cofradía de la Sangre de Alcoy en Corrientes espirituales en la Valencia del siglo XVI (1550-1600), "Actas del II Symposion de Teología Histórica (Valencia, 20-22 de abril de 1982)», Valencia, 1983, pp. 391-399.

${ }^{66}$ M.M. CÁRCEL ORTí, Capítulos de la cofradía de la Sangre de Cullera en "Quaderns de Sueca", III (1982), pp. 81-93.
} 
Tampoco en ambas cofradías valencianas hay datos sobre la sociología de sus miembros tal y como ha podido tratarse en Zaragoza o Castellón.

Por otro lado, las primeras noticias disponibles sobre las cofradías de Alcoi (1545), Cullera (1546) y Castellón (1549) llaman la atención sobre un hecho importante. ¿Sirvió de modelo la ciudad de Valencia al respecto? ¿Qué se sabe de la cofradía de la Sangre de Valencia? El padre Teixidor alude a un milagro ocurrido en Mislata que fue el origen del culto a la Sangre de Cristo en el reino de Valencia. Al crecer esta devoción el papa Paulo III instituyó una fiesta conmemorativa con una bula fechada el 14 de abril de 1540. A causa de ello, en la ciudad de Valencia se creó una cofradía cuyas constituciones fueron aprobadas por el vicario general diocesano el 15 de marzo de 1535. En un principio los cofrades no tenían casa para reunirse pero el 11 de marzo de 1538 compraron el Hospital de la Reina y allí constituyeron su iglesia de la Sangre ${ }^{67}$. La relación de la diócesis del año 1610 explica que en el ámbito de la parroquia de San Martín en la ciudad de Valencia hay una casa y cofradía de la Sangre de Christo donde hay muchos cofrades legos para la disciplina del Jueves Santo, tienen sus constituciones visitadas por el ordinario y dicen misas por los cofrades ${ }^{6}$. No se pierda de vista que en 1596 el patriarca San Juan de Ribera fundó el convento de la Sangre de Cristo en un lugar provisional de Valencia y que el 27 de julio de 1605 está fechada la bula del papa Paulo V por la que se constituye la Provincia Capuchina de la Preciosísima Sangre de Cristo de Valencia ${ }^{69}$.

En 1610, también en Xàtiva se registra una cofradía de la Sangre según la relación de la diócesis: Una cofradía de la Sangre de Christo para la disciplina del Jueves Sancto instituida en el monasterio de San Francis$c o$, con sus constituciones visitada por el ordinario ${ }^{70}$. Idéntica noticia se recoge para Gandía donde hay otra cofradía de la Sangre de Cristo con su casa, capilla y constituciones, visitada por el ordinario, que sirve para la disciplina del Jueves Santo ${ }^{71}$. La de Xàtiva existía cuarenta años antes por lo menos a tenor de un inventario de bienes de la cofradía del año 1569, en el cual se reseñan entre otras cosas un crucifijo para la procesión del Jueves Santo y otro de madera con un Cristo pintado para que lo llevaran con sus propias manos los sentenciados ${ }^{72}$.

En contraste con todos estos ejemplos valencianos, parece que la cofradía de la Sangre de Barcelona fue fundada en 1547 por otra bula papal y tuvo su sede en la capilla del Santísimo Sacramento de la Iglesia de Nues-

\footnotetext{
${ }^{67}$ J. TEIXIDOR, Antigüedades de Valencia, Valencia, 1895, tomo II, pp. 359 y siguientes.

${ }^{68}$ Relaciones sobre el estado de las diócesis valencianas, citado, p. 725.

${ }^{69}$ J.V. CiURANA Viguer, Fundación y fundadores de la Provincia Capuchina de Valencia, Valencia, Curia Provincial de Hermanos Menores Capuchinos, 1996.

${ }^{70}$ Relaciones sobre el estado de las diócesis valencianas, citado, p. 744.

${ }^{71}$ Ibídem, p. 747.

${ }^{72}$ J. Bellver Blasco, Cofradía de la Purísima Sangre de Cristo, citado, pp. 66-67.
} 
tra Señora de los Reyes, también llamada del Pino ${ }^{73}$. Tengo noticias sobre cofradías bajo esta misma advocación erigidas en el siglo XVI en Tarragona, Alicante, Sagunto y otras muchas partes de la Corona de Aragón, por no citar el Hospital de la Sangre de Palma de Mallorca o las iglesias de la Sangre de Onda o Llíria. Ocurre aquí como en el caso de la Vera Cruz. Las pistas son numerosas y hay que sondearlas de manera rigurosa y sistemática, comparando los ejemplos identificados unos con otros sin seguir cayendo en la erudición localista que no mira más allá de su estrecha realidad puntual. Los estudios existentes sobre cofradías en la Corona de Aragón serán muy útiles en la búsqueda de respuestas ${ }^{74}$. ¿Existe alguna relación clara entre las fundaciones de cofradías de la Sangre en unos y otros lugares? ¿Quiénes están detrás del detonante que institucionaliza una devoción en forma de hermandad cofrade bajo su advocación?

\section{BALANCE PROVISIONAL}

En los reinos hispánicos de la Edad Media, diversas devociones sobre la Cruz y la Sangre de Cristo revitalizadas por el fenómeno de las Cruzadas y el ideal de la Reconquista pasaron a integrarse a partir del siglo XIV en cofradías penitenciales bajo la advocación de la Vera Cruz. El fenómeno se completó a partir del siglo XVI cuando proliferaron en España otras cofradías dedicadas a la Sangre de Cristo que eran muy parecidas en líneas generales a las de la Vera Cruz, hasta el punto de poder afirmarse, en efecto, que ambos tipos de entidades convergen en el origen de la $\mathrm{Pa}$ sión o de la Semana Santa bajo dos advocaciones diferentes que incluso muchas veces aparecen unidas. La verdad es que si bien prevaleció en Castilla el título de la Vera Cruz, en los territorios de la Corona de Aragón destaca más la dedicación a la Sangre de Cristo, aunque ello no significa que no existiesen algunas bajo la advocación de la Vera Cruz, y no sólo la de Xàtiva como se creía hasta ahora. Lo que todavía no me queda claro y tendremos que seguir investigándolo es el motivo por el cual las cofradías de la Corona de Aragón adoptaron preferentemente el título de la Sangre

\footnotetext{
${ }^{73}$ Real Ilustre Archicofradía de la Purísima Sangre de Nuestro Señor Jesucristo de Barcelona, Barcelona, 1914.

${ }^{74} \mathrm{~A}$ destacar, aparte de la bibliografía ya citada en este artículo los estudios de I. ESCAGES JAVIERRE, Cofradías de hijosdalgo del medioevo aragonés en "Hidalguía", 28 (1980), pp. "Boletín de la Sociedad Castellonense de Cultura" LVIIII (1982) pp. 5-58; J J F. CABESTANY FORT Confraries $i$ gremis a Barcelona Segles XIII al XVI en "Finestrelles" . 2 (1990) pp. 141-145: G. ENSENYAT PUIOL, Notes sobre els primers gremis $i$ confraries coneguts a Malp 14 (seoles XIII-XVI) en lus actas del sobre els primers gremis i confraries coneguts a Mallor ca (segles XIII-XVI) en las actas del congreso La manufactura urbana i els menestrals (segles XIII-XVI, Palma de Mallorca, 1991, pp. 247-250; A. HEVIA BALLINA, Las cofradias en la vida de la Iglesia: un mundo de comunicación para la piedad y la caridad. Un censo de documentación de cofradías de la Iglesia en España en las actas del congreso Los archivos de la Iglesia, presente y futuro, Barcelona, 1990, pp. 77-108; y J. SÁNCHEZ HERRERO, Las cofradias alicantinas y valencianas y su evolución durante los siglos XIII al XVI en las actas del congreso 1490. En el umbral de la Modernidad. Las ciudades y el Mediterráneo de los siglos $X V$-XVI, Valencia, 1994, pp. 301-363.
} 
frente a las castellanas que optaron por el de la Vera Cruz, hasta el punto de que las pocas cofradías aragonesas de la Vera Cruz que hubo fueran promovidas principalmente por reinas castellanas como Leonor, segunda esposa de Alfonso IV de Aragón, o María, casada con Alfonso V el Magnánimo. No se olvide, sin embargo, que las primeras cofradías de la Vera Cruz que se fundan en el vecino reino de Navarra son de la segunda mitad del siglo XVI y no anteriores, y surgen en aplicación de las disposiciones establecidas por el propio Concilio de Trento ${ }^{75}$.

Según Fermín Labarga, no es extraño que para estas cofradías, llámense de la Vera Cruz o de la Sangre de Cristo, una de sus principales devociones sea la de las Cinco Llagas, como plasma el escudo de la de Alcoi. El culto y la devoción a las cinco llagas de Cristo (las de los cuatro clavos y la de lanza clavada en el costado) también se encuentran estrechamente relacionados con la devoción a la Sangre de Cristo y, lo mismo que ésta, con el muy importante culto a la adoración que la Iglesia tributa a la Santa Cruz. La popularidad de este culto comenzó de hecho en la Edad Media y está en relación directa con el ejercicio de la disciplina, la flagelación y, en definitiva, el derramamiento de la sangre por los demás. Un buen ejemplo iconográfico al respecto aparece en un cuadro perteneciente al Hospital de la Sangre de Palma de Mallorca. En la iglesia de dicho hospital se fundó a mediados del siglo XVI la cofradía de la Preciosa Sangre cuyos hermanos se disciplinaban en la procesión de tarde-noche del Jueves Santo ${ }^{76}$.

En su estudio sobre las cofradías de la Vera Cruz en Castilla la Nueva, la profesora Ángela Muñoz ${ }^{77}$ resumía la peculiaridad de este tipo de asociaciones religiosas a partir de los siguientes componentes: orientación cristocéntrica; imágenes de Cristo crucificado, fiestas específicas (Jueves Santo, Viernes Santo, Invención de la Cruz el 3 de mayo, Exaltación de la Cruz el 14 de septiembre, Triunfo de la Cruz el 16 de julio, Resurrección, Corpus Christi); disciplina y procesiones penitenciales con flagelación; distinción entre cofrades de la disciplina o de la sangre y cofrades de la luz que no participaban en la disciplina al igual que las mujeres porque estaban excluídas desde el principio. Es curioso que el título de la Vera Cruz para estas cofradías de Castilla la Nueva aparece con no poca frecuencia asociado al de la Sangre de Cristo y en una proporción considerablemente inferior se registra el título de la Sangre de Cristo por sí solo, a la inversa de lo

${ }^{75}$ G. SILANES SUSAETA, Las cofradías de la Vera Cruz en el reino de Navarra (siglos XVI-XVIII) en "Hispania Sacra", 52/106 (2000), pp. 457-478.

${ }^{76}$ Dato proporcionado por el mismo F. LABARGA GARCÍA, La Pasión centro de la espiritualidad de las cofradías de la Vera Cruz en M. García-Esteller y D. Martín (eds.) A Actas del II Congreso Internacional de la Vera Cruz, citado , pp. 341-360. V́éase también la tesis doctoral de este autor publicada con el título Las cofradias de la Vera Cruz en La Rioja. Historia y espiritualidad, Logroño, 2000.

${ }^{77}$ A. MUÑoz FERNÁndeZ, Las cofradías de la Vera Cruz en Castilla la Nueva. Siglos $X V-X V I I I$ en J. Sánchez Herrero (dir.), Las cofradías de la Santa Vera Cruz, citado, pp. 183205 . 
que sucede en la Corona de Aragón. Ahora bien, hay que reconocer que en ambas partes el modelo de cofradía de Semana Santa más antiguo siempre es el de la Vera Cruz, el cual empezará a difundirse a gran escala durante la segunda mitad del siglo XVI por toda España, gracias a esas indulgencias concedidas por la bula del papa Paulo III en 1536 a petición del cardenal Francisco de Quiñones. De esa manera, años después con el concilio de Trento, las cofradías españolas de la Vera Cruz acabaron por convertirse en ejemplo depurado de hermandad contrarreformista.

Creo haber podido demostrar que las reliquias jugaron un papel fundamental en la construcción de las identidades culturales, jerarquizadas incluso entre ellas según el grado de prestigio que se les atribuía por parte de la monarquía y la iglesia. Las más valiosas, desde luego, eran las de la Pasión: la Vera Cruz, el Santo Cáliz, la Sangre de Cristo, los Corporales, el Santo Sudario, la Corona de Espinas, la Santa Faz, el Velo de la Verónica, la Lanza de Longinos, la Tierra del Santo Sepulcro. Clérigos y nobles, papas y reyes construyeron mitos y leyendas que atrajeron todavía más la atención de la sociedad por estos objetos tan preciados y de un valor incalculable. Esas gentes cultas establecieron las bases del fervor popular por las reliquias y sus milagros (dominicos, franciscanos). Pero también por la exaltación pública de dichas creencias mediante procesiones cívicas (como el Corpus Christi) o de disciplinantes (las promovidas abiertamente por San Vicente Ferrer). Son muchos fenómenos, pues, los que convergen juntos en crear el ambiente propicio para la eclosión del movimiento confraternal de la Vera Cruz y de la Sangre de Cristo en la Corona de Aragón, liderado por los grupos dirigentes y las personas más poderosas de cada lugar, cuando no por las gentes de la burguesía y los labradores. La cronología de las fundaciones no es casual. Responde a una institucionalización de identidades culturales que ya eran latentes en cada contexto local años antes de que las bulas papales o los concilios intentaran regularizar y homogeneizar los comportamientos religiosos de la población. El reto de los investigadores radica a partir de ahora en aunar esfuerzos en la comprensión global de este fenómeno con una apuesta firme y rotunda por la historia comparada.

Fecha de recepción del artículo: mayo 2006.

Fecha de aceptación y versión final: junio 2006. 